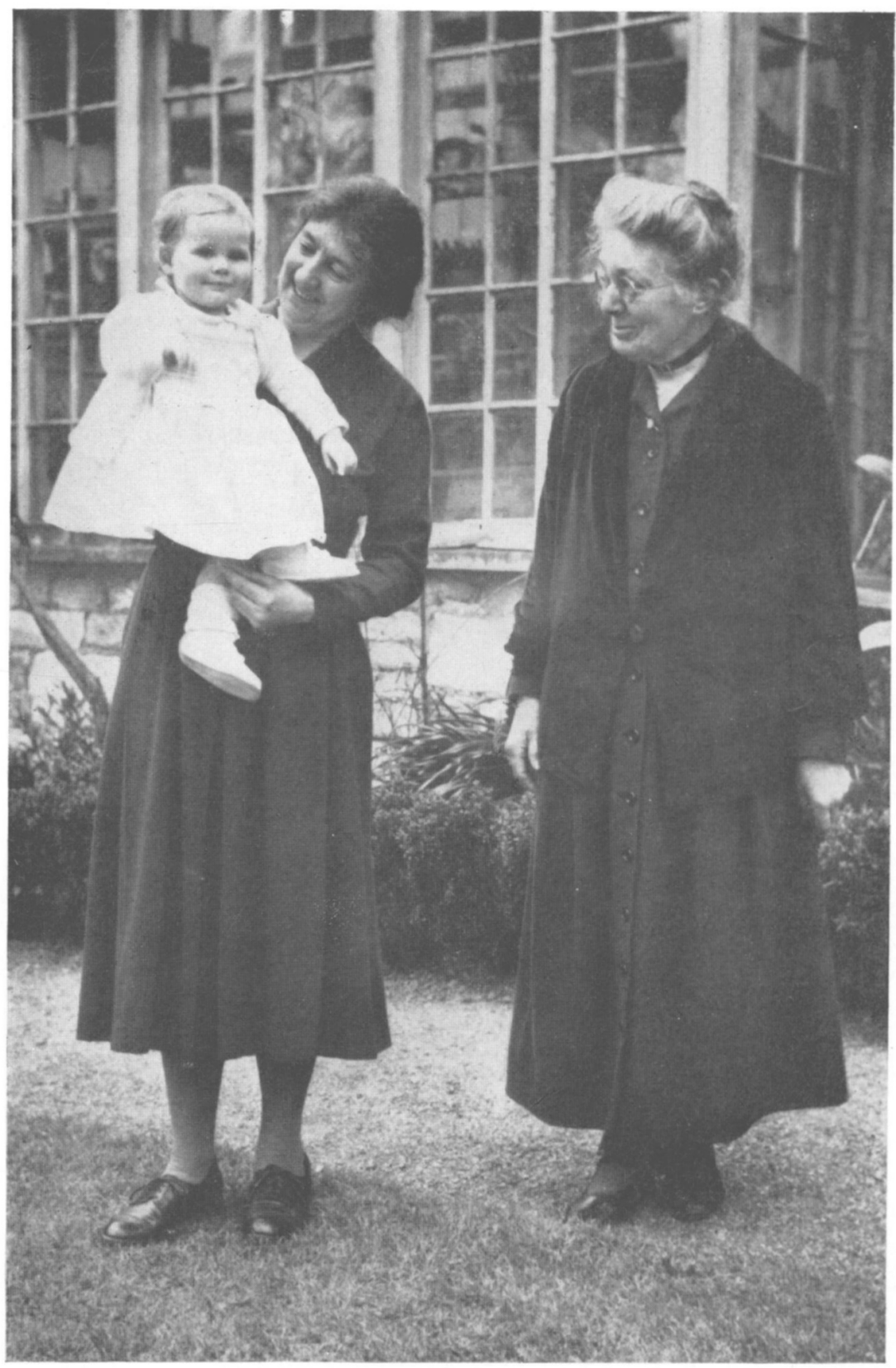

\title{
Solo Sexton:
}




\title{
OBITUARY
}

\author{
MRS E. W. SEXTON, F.L.S. (1868-1959)
}

Mrs Alice Wilkins Sexton (née Wing) was born at Truro on 27 April I868 and brought up by parents who, as she related, regarded natural science as no fit subject for a young lady, nor believed it proper for young ladies to study at colleges. Her later life revealed itself as a splendid reaction to this upbringing.

During her childhood some periods were spent in Banffshire and Galway, but a permanent change of surroundings occurred in 1885 when the family moved from Truro to Plymouth. Here she later married Mr L. E. Sexton, a dental surgeon with scientific interests, a keen supporter of the Plymouth Athenaeum, and a friend of the late Dr E. J. Allen. In $1900 \mathrm{Mr}$ Sexton became a member of the Marine Biological Association. An outlet was now provided for his wife's interest in animals and exceptional talent for drawing and painting. As can be seen from her oldest surviving sketches, it is in this year that Mrs Sexton's work in the field of marine biology properly began.

Polychaete worms and Crustacea provided her main subject matter. The first illustrations to be published (in 1902) were twelve plates in T. V. Hodgson's report on the Crustacea of the 'Southern Cross' expedition. She then illustrated certain polychaetes for two of Dr Allen's papers published in 1904. ${ }^{1}$ Further drawings of crustaceans and pycnogonids illustrated articles by L. H. Gough, ${ }^{2}$ T. V. Hodgson, ${ }^{3}$ and R. Gurney. ${ }^{4}$ All these appeared under the signature of 'E. W. Sexton', from the circumstance that the name 'Elsie' had been adopted in place of Alice, and this name was never after to be discarded.

These earlier drawings showed an unusual ability for depicting detail accurately, a feature that was to be so conspicuous in her later work. Examination of the plates in Hodgson's 'Southern Cross' Report gives no clue that these were in fact reproduced without any reduction.

It is not surprising, then, that Prof. McIntosh accepted some of her illustrations of syllids for the current volume of his polychaete monograph (Vol II, No. I), notwithstanding the very high standard set by Miss A. Watson, his regular artist. Some coloured illustrations of the syllid Procerastea, included in three plates of Allen's paper ${ }^{5}$ published in the Phil. Trans. much later on,

1 F.M.B.A., Vol. 7, p. 299 and Q.F.M.S., Vol. 48, p. 79 (1904).

2 Report on the plankton of the English Channel in 1903.

3 Ann. Mag. nat. Hist. (7), Vol. 14, p. 458, and National Antarctic Exped. 1901-4, Vol. 3.

4 Spolia Zeylanica, Vol. 4, p. 126.

s Phil. Trans. B, Vol. 21 I, p. I3I (1921). 
in I921, can only be described as wonderful. Many, however, of her drawings and paintings of polychaetes have never been published: they survive in two albums (one started in 1901, and the other, the larger, in 1909).

But Mrs Sexton was not destined to remain simply an illustrator. In August 1906 Dr Allen went on a 5-day cruise in the S.S. 'Huxley' to the northern part of the Bay of Biscay and brought back a collection of invertebrates. He offered the Amphipoda to Mrs Sexton to examine. This task she set about with vigour and thoroughness. By the time she had dealt with the thirty-five species represented she had made contact with the leading specialists of the day, obtained :oans of type material from several Museums, and had gone far in becoming a specialist herself in the study of Amphipoda. This group was, in fact, to provide the chief subject of her work for the rest of her life. Her first publications appeared in the Proceedings of the Zoological Society of 1908 and 1909, two first-rate taxonomic papers. ${ }^{1}$ To a reader of these to-day it is difficult to realize that the author had had no academic zoological training.

While continuing taxonomic studies-collections from Hamburg and Königsberg Museums were next examined-Mrs Sexton now embarked on a plan to study in detail the life-history of a species that could easily be reared in the laboratory. Among Amphipoda almost nothing was then known of the number of stages passed in reaching maturity, or of the degree of change between one stage and the next. Fassa was first chosen, but after considerable effort the difficulty of breeding it proved too great. Its study, though renewed later, was eventually abandoned, not altogether without results of interest. ${ }^{2}$ Attention was then turned to Gammarus.

It happened that both the German collections were mainly from brackish and fresh water, and contained various samples of an unnamed Gammarus previously confused either with $G$. locusta or with $G$. duebeni. Though particularly struck by the fact that the animals from the more saline localities were less hairy than those from fresher water, Mrs Sexton assigned them all to a single variable species, which she described as $G$. zaddachi. Various localities were then examined near Plymouth for Gammarus, and overlooked species were discovered (though, curiously, zaddachi itself remained unobserved until it was pointed out by a visitor from Australia twenty years later). Notably, a collection from the brackish ditches of Chelson Meadow, made on 4 June I9I2, produced in abundance a distinct species of smallish size, to be described by Mrs Sexton as G. chevreuxi. For many years Chelson Meadow was its only known habitat. Two pairs of the original collection were set aside for detailed observation and for providing broods for experimental rearing in different salinities. Mrs A. Matthews assisted in this research, which was carried out in the Plymouth Laboratory: up to now Mrs Sexton

1 P.Z.S. (1908): p. 370; (1909): p. 848.

2 Sexton \& Reid (195I), J. Linn. Soc., Vol. 42, p. 29. 
had apparently worked in her own home in Higher Compton under $\mathrm{Dr}$ Allen's remote control.

The results were unexpectedly fruitful, for they led to an entirely unforeseen line of research. For it was from the progeny of one of these pairs that the first mendelian recessive type was bred out-an animal with red, instead of black, eyes. Other variations affecting the eye pigments were soon observed, some behaving in a simple mendelian manner, others not. These were still relatively early days in the study of the new genetics, and hardly any invertebrates other than insects had been studied for mendelian inheritance. The outcome of the extensive breeding work then undertaken with the collaboration of Dr Allen was looked upon with more than ordinary interest, and G. chevreuxi began to attract attention as a useful experimental animal.

The occurrence of intersexes in one of the laboratory strains provided the occasion, in 1920, for collaboration with a rising young zoologist, J. S. Huxley, in an attempt to trace the cause of this phenomenon. While genetic work continued, the original aim of making a detailed study of the life-history of $G$. chevreuxi was eventually achieved in 1924. The successive stages of both male and female are illustrated in detail, based on the examination of successive moults of numerous individuals, and the result is a classic of its kind.

In the mean time the genetic work had received a new stimulus with the appearance of more red-eye recessive types in collections made in 1922, and another recessive concerned with the lack of body pigment. An additional incentive about this time was the belief that the 'mutant' types may have originated under the influence of heat or other abnormal conditions. As work continued through the years into the 1930's it was appreciated by degrees that the wild population carried a high proportion of recessive genes which were exposed in the laboratory by in-breeding. This in itself is a fact of much interest, its cause and significance being still imperfectly understood.

One of the mutant strains was kept going for many years in the Oxford Zoological Laboratory, where E. B. Ford used it successfully, not only in practical genetic classes but also experimentally in illustrating the essentially dynamic action of genes. Mrs Sexton had always appreciated the opportunities that Gammarus afforded for tracing the development of any given character during successive growth stages, a possibility not afforded by holometabolous insects like Drosophila.

Not long after the death of her husband Mrs Sexton was appointed to the Laboratory staff, on I April 1924, as the Director's Research Assistant, a post she held until 1948 when she officially retired. She had just completed a guide to the Plymouth aquarium, which L. R. Brightwell illustrated.

During the years that followed, the work involved in maintaining the diverse 'mutant' stocks of Gammarus chevreuxi became particularly arduous. The variety of eye-colour types had multiplied and required careful assessment. 
A continuous succession of broods had to be sorted, their characters noted, and periodically re-examined; pairs had to be intelligently mated, and dead animals preserved; then histories had to be catalogued, and the final results charted. This task she fulfilled with never more than one part-time assistanther sister Miss M. B. Wing at the beginning and then, for at least 20 years, Miss A. R. Clark. ${ }^{3}$ The genetic work on $G$. chevreuxi was not wound up until 1936.

After this Mrs Sexton turned to accumulated arrears of Gammarus taxonomics, describing $G$. tigrinus from the Midlands, giving a revised account of Marinogammarus species (in collaboration with G. M. Spooner), and writing a fuller description of Gammarus zaddachi. Finally she produced a very complete review of fassa falcata, including results of her earlier unpublished work, a task in which she was helped by the late D. M. Reid. She passed her 8oth birthday before the latter work was completed, yet her ability to produce accurate illustrations showed no sign of deterioration. It was her failing eyesight that eventually called a halt to her remarkably sustained scientific activity. In 1957, after the death of her only daughter Mary in I95I, she left Plymouth to spend her remaining years with her son, Col. F. B. W. Sexton, in Sussex. She died on 18 February 1959 in her 9Ist year.

Mrs Sexton had great vitality, determination, and independence of outlook. Those who, on rare occasions, offered direct or implied criticism of her work were summarily treated, student ${ }^{1}$ and professor $^{2}$ alike. She held firmly to any belief she had once formed.

Her great contribution was the excellence of her illustrations and descriptions. There is rarely any doubt what she is describing, and later specialists can rely on her data for forming their own interpretations. In drawing amphipods and their parts she is superior even to G. O. Sars, for paying that much more critical attention to detail. Her technique, moreover, had to be accommodated to the requirements of the line-block and dispense with shading effects, a limitation Sars never had to contend with.

Those who were privileged to know her found in her a generous and sympathetic friend. Visitors to her home at Reservoir House (to which she moved after her husband's death) were received with the kindest hospitality. Her garden was full of botanical treasures from all over the world, and these she exhibited with delight. She had special regard for young biologists whom she was always eager to help. For children also she had a particular fondness, and the photograph here reproduced shows a characteristic aspect. With her, holding a child, is her daughter Mary (Miss M. A. F. Sexton) who was Librarian at the Plymouth Laboratory when she died in I95I.

G.M.S.

i Nature, Lond., Vol. 136, p. 477.

2 F.M.B.A., Vol. 21, p. 407 .

a F.M.B.A., Vol. 40, p. 459. 